\title{
THE MECHANICAL FRAGILITY OF THE RED CELL IN PATIENTS WITH LEAD POISONING
}

\author{
BY \\ A. J. de KRETSER and H. A. WALDRON \\ From the Medical Department, Vauxhall Motors Ltd., Luton, Beds.
}

(RECEIVED FOR PUBLICATION JANUARY 29, 1963)

\begin{abstract}
Observations on the mechanical fragility of the red cell in 68 workers having had exposure to lead in varying degrees, and on blood to which lead had been added in vitro in concentrations up to $5 \mu \mathrm{g}$./ ml., showed that the mechanical fragility index did not vary significantly from that of a control group.

Furthermore, the use of various anticoagulants produced no significant alterations in the mechanical fragility index. It was found, however, that in subjects suffering from anaemia of varying types, the mechanical fragility index was always greatly increased if the haemoglobin was below $80 \%$.
\end{abstract}

\section{Introduction}

Following observations on the behaviour of leaded red cells in Ringer's solution, Aub, Fairhall, Minot, and Reznikoff (1926) postulated the theory that the primary cause of the anaemia associated with lead poisoning was that lead increased the mechanical fragility of the erythrocyte by interfering with the structure of the red cell envelope.

Later, Rimington (1938) suggested that lead interfered with the incorporation of iron into the protoporphyrin IX molecule and he discounted the haemolytic action of lead.

Since then various authorities have put forward evidence to support one or other of these views.

A review of the literature led us to believe that no one had in fact estimated the mechanical fragility of leaded red cells or of red cells from persons exposed to lead, using one of the methods derived from that originally described by Shen, Castle, and Fleming (1944).

We therefore decided to undertake such an investigation using our own variation of the technique of Shen et al. The apparatus used (Fig. 1) was made in our own laboratory and was basically that of Young, Izzo, and Platzer (1951).

\section{Methods}

The mechanical fragility index was determined as follows: Two one-millilitre samples of freshly collected whole blood were introduced into small "pyrex" Ehrlenmeyer flasks of $50 \mathrm{ml}$. capacity, and to each were added 10 lead-free glass beads of $4 \mathrm{~mm}$. diameter.

The flasks were then attached to the apparatus shown (Fig. 1) and rotated at 28 r.p.m. for 90 min. \pm 1 minute. At the end of this time the two samples were pooled and 20 c.mm. taken into $5 \mathrm{ml}$. $0.4 \% \mathrm{v} / \mathrm{v}$ ammonium hydroxide solution $=100 \%$ haemolysis. A further 20 c.mm. was taken into $0.85 \% \mathrm{w} / \mathrm{v}$ sodium chloride solution in a centrifuge tube and centrifuged at 1,000 r.p.m. for 5 min., after which time the supernatant fluid was decanted into a clean tube.

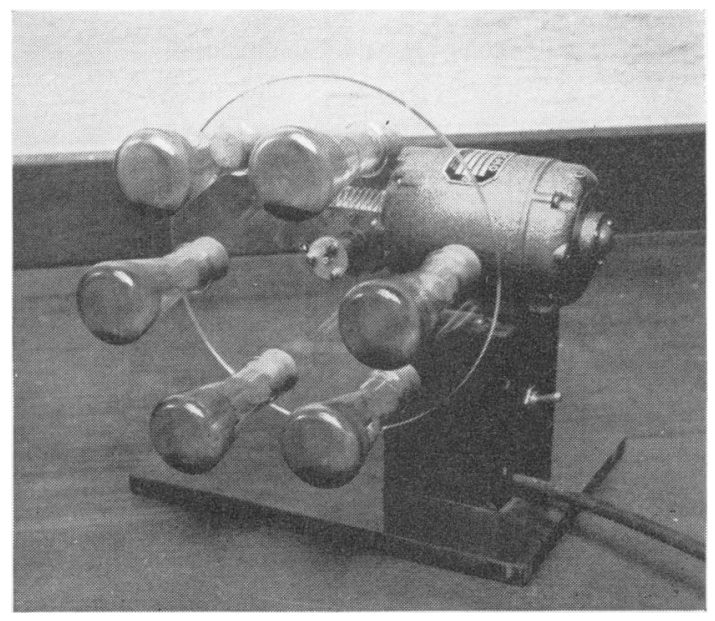

FIG. 1.-The apparatus. 
The percentage observed haemolysis (O.H.) was calculated by measuring the extinction of the supernatant fluid against the $100 \%$ haemolysis solution in the spectrophotometer at a wavelength of $540 \mathrm{~m} \mu$, using a cell of 1 $\mathrm{cm}$. optical path. De-ionized water was taken as the blank.

At the same time the packed cell volume (P.C.V.) of the blood sample under test was determined by centrifuging some of the blood in a haematocrit tube at 3,000 r.p.m. for 30 minutes.

The mechanical fragility index (M.F.I.) was then calculated thus:

$$
\text { M.F.I. }=\text { O.H. } \times \frac{45}{\text { P.C.V. }}
$$

Normal red cells from persons having had no exposure to lead were leaded in the following manner. A measured amount of a standard solution of lead acetate was taken into lead-free glass tubes, enough to give final concentrations of $1,2,3,4$, and $5 \mu \mathrm{g} . / \mathrm{ml}$. of blood. The tubes were placed in an incubator at $37^{\circ} \mathrm{C}$. and the lead acetate was allowed to dry. When dry, exactly $3 \mathrm{ml}$. of heparinized blood was added and the tubes were mixed thoroughly by gentle inversion. The blood was allowed to equilibrate for $90 \mathrm{~min}$. at $37^{\circ} \mathrm{C}$. After this time the action of the lead was stopped by transferring the blood into tubes containing dried di-sodium E.D.T.A., and, after mixing, the M.F.I. was determined on the leaded blood.

Blood lead estimations, punctate basophil count, and haemoglobin concentration were determined by the methods described in a previous article (de Kretser and Waldron, 1963).

\section{Results}

Our results do not confirm the findings of Aub, Minot, Fairhall, and Reznikoff (1924) that lead is responsible for an increase in the mechanical fragility of red cells (Table 1). In fact the impression from Fig. 2, a percentage histogram, is that the red cells of our lead workers were more resistant to mechanical haemolysis than those of a normal control group with no exposure to lead.

Various anticoagulants were used to determine whether they had any effect on the M.F.I. This was found not to be so (Table 1). The importance of

TABLE 1

MECHANICAL FRAGILITY INDEX IN LEAD-EXPOSED WORKERS AND IN A CONTROL GROUP WITH THE USE OF VARIOUS ANTICOAGULANTS

\begin{tabular}{|c|c|c|c|c|}
\hline Anticoagulant & No. & Mean & $\begin{array}{l}\text { Standard } \\
\text { Deviation }\end{array}$ & Range \\
\hline $\begin{array}{l}\text { Control Group } \\
\text { Oxalate } \\
\text { diPotassium E.D.T.A. } \\
\text { Heparin } \\
\text { Whole group }\end{array}$ & $\begin{array}{l}10 \\
32 \\
27 \\
69\end{array}$ & $\begin{array}{l}11 \cdot 80 \\
11 \cdot 80 \\
11 \cdot 21 \\
11 \cdot 62\end{array}$ & $\begin{array}{l}2 \cdot 24 \\
2 \cdot 34 \\
1 \cdot 56 \\
1 \cdot 73\end{array}$ & $\begin{array}{l}7 \cdot 32-16 \cdot 28 \\
7 \cdot 12-16 \cdot 48 \\
8 \cdot 09-14 \cdot 33 \\
8 \cdot 16-15 \cdot 08\end{array}$ \\
\hline $\begin{array}{l}\text { Test Group } \\
\text { diPotassium E.D.T.A. } \\
\text { Heparin } \\
\text { Whole group }\end{array}$ & $\begin{array}{l}15 \\
53 \\
68\end{array}$ & $\begin{array}{l}10 \cdot 83 \\
10 \cdot 25 \\
10 \cdot 38\end{array}$ & $\begin{array}{l}1.99 \\
2.01 \\
1.96\end{array}$ & $\begin{array}{l}6 \cdot 85-14 \cdot 81 \\
6 \cdot 23-14 \cdot 27 \\
6 \cdot 46-14 \cdot 30\end{array}$ \\
\hline
\end{tabular}

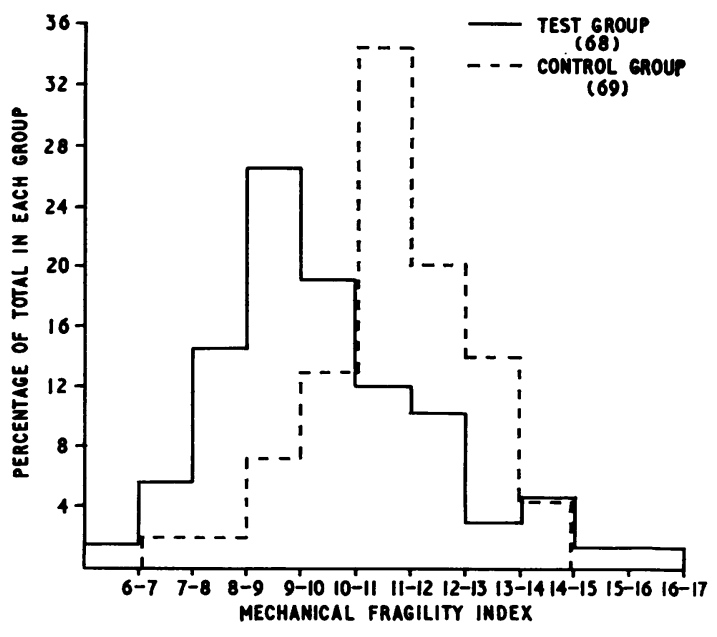

FIG. 2.-Histogram of mechanical fragility index in lead-exposed workers with control group for comparison. Note apparent shift to left.

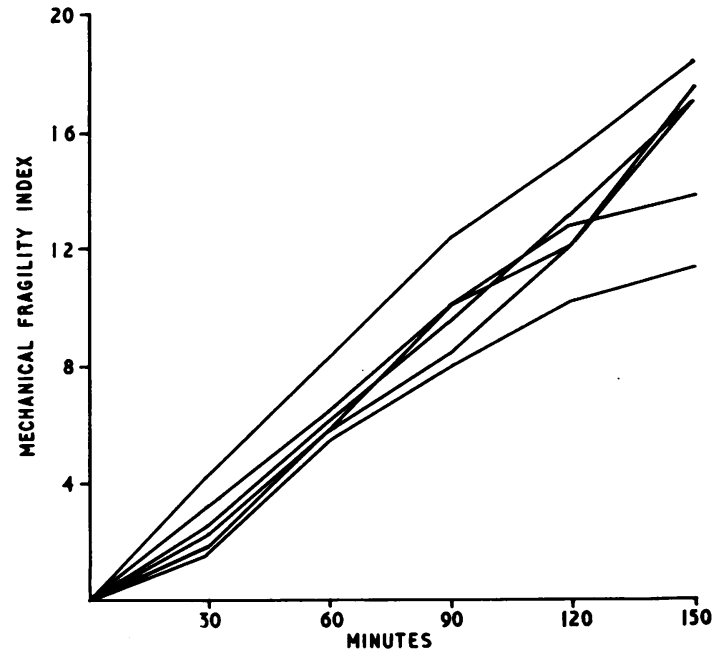

FIG. 3.-Graph showing the increase in mechanical fragility with the increase in time of rotation.

exact timing in these experiments is shown in Fig. 3, which demonstrates that the M.F.I. increases with increasing time of rotation. This finding is in accordance with that of Schubothe and Po-Tun Fok (1960).

Increasing concentrations of lead were added to normal blood in vitro, as described in the methods, up to a concentration of $5 \mu \mathrm{g} . / \mathrm{ml}$. The results of the M.F.I. determined on these cells are shown in Table 2 and accord with the findings for our lead workers.

We wondered whether a fall in haemoglobin per se resulted in an increased M.F.I., and accordingly we 
TABLE 2

THE MECHANICAL FRAGILITY OF BLOOD TO WHICH LEAD HAD BEEN ADDED IN VITRO

\begin{tabular}{|c|c|c|c|c|c|}
\hline & \multicolumn{5}{|c|}{ Lead $(\mu \mathrm{g} . / \mathrm{ml})}$. \\
\hline & 1 & 2 & 3 & 4 & 5 \\
\hline M.F.I. & $\begin{array}{r}8.78 \\
13.94 \\
9.59 \\
9.48 \\
6.89\end{array}$ & $\begin{array}{r}7.70 \\
9.18 \\
10.01 \\
9.89 \\
7.67\end{array}$ & $\begin{array}{r}9 \cdot 12 \\
8.07 \\
12.33 \\
16.71 \\
13.38\end{array}$ & $\begin{array}{r}9.12 \\
8.66 \\
13.76 \\
11.11 \\
12.07\end{array}$ & $\begin{array}{r}9 \cdot 12 \\
8.66 \\
11 \cdot 17 \\
8.07 \\
10 \cdot 78\end{array}$ \\
\hline$\overline{\text { Mean }}$ & $9 \cdot 74$ & 8.89 & 11.92 & 10.94 & 9.54 \\
\hline
\end{tabular}

collaborated with the local hospital to obtain fresh samples of blood from six anaemic patients, the blood being collected by one of us (H.A.W.). The M.F.I. was performed within an hour of collection because we found that blood stored at room temperature, $20^{\circ} \mathrm{C} . \pm 2^{\circ}$, became more mechanically fragile on standing, presumably due to intrinsic metabolic changes in the red cell. From Table 3 it will be seen that the M.F.I. was substantially increased in all six anaemic patients. It was our initial hope to repeat our experiments on a group of

TABLE 3

THE MECHANICAL FRAGILITY INDEX IN SIX PATIENTS WITH SEVERE ANAEMIA

\begin{tabular}{c|c|c|c|c|c|c}
\hline $\begin{array}{c}\text { Haemo- } \\
\text { globin } \\
(\%)\end{array}$ & 28 & 40 & 52 & 54 & 62 & 64 \\
\hline M.F.I. & 30.94 & 24.95 & $51 \cdot 63$ & $21 \cdot 80$ & $30 \cdot 12$ & $34 \cdot 31$ \\
\hline
\end{tabular}

patients with frank clinical plumbism, but the difficulties in obtaining fresh blood samples from such patients appear too numerous to circumvent.

\section{Discussion}

Since Laennec in 1831 described thinness of the blood in patients with lead poisoning (Hunter, 1962), the mechanism by which lead causes anaemia has been the subject of much discussion and controversy.

The fact that lead interferes with haemopoiesis is now well established. In 1938 Rimington first advanced the theory that lead prevented the incorporation of iron into the protoporphyrin IX molecule. The work of Vigliani and Waldenström (1937), and the later work of Rimington (1951), Goldberg, Ashenbrucker, Cartwright, and Wintrobe (1956), Gajdos-Török, Gajdos, and Bénard (1958), Bénard, Gajdos, and Gajdos-Török, (1958) and Jandl, Inman, Simmons, and Allen (1959), using isotope techniques, has given support to this theory.

The suggestion that lead had an effect on the circulating red cell was put forward by Aub, Minot,
Fairhall, and Reznikoff (1924) as a result of their extensive studies on leaded red cells in which they showed that, in diminishing concentrations of Ringer's solution, the red cell became crenated, lost its power of agglutination and cohesion, and that the cells affected haemolysed less readily than normal cells. They also found (Aub et al., 1926) that leaded red cells were more resistant to haemolysis in hypotonic saline. From these observations they inferred that leaded red cells were more mechanically fragile than normal cells and that consequently they broke up more rapidly when subjected to the trauma attendant on passage through the capillaries, thus giving rise to the anaemia commonly associated with lead poisoning.

Shen et al. (1944) showed that increased powers of cohesion and agglutination caused an increase in mechanical fragility. Also cells from patients with congenital haemolytic anaemia, i.e. cells whose shape tended to be spheroidal, were shown to have an increased mechanical fragility compared to the findings in normal cells. Futhermore, they reported that experimental work indicated a relation between the osmotic and mechanical fragilities of the erythrocyte, the one increasing or decreasing pari passu with the other.

Pearse (1926) and Clarkson and Kench (1958) showed that the leaded red cell had an increased resistance to haemolysis in hypotonic saline, and Clarkson and Kench concluded from their studies that in vivo plasma lead will give rise to only minimal changes in the fragility of circulating red cells.

Taking these sets of observations together, one is drawn to the conclusion that, unless lead alters the red cell membrane, the findings of Aub et al. indicate that the mechanical fragility of leaded red cells should be lowered and not raised. Since Dacie (1962) showed that the integrity of the red cell membrane is dependent on the internal metabolism of the cell, this is tantamount to saying that the lead must exert its effect on the fundamental metabolism of the red cell for the conclusion of Aub and his colleagues to be valid. Although our results failed to confirm the contention of Aub et al. that the mechanical fragility of the red cell in patients with lead poisoning is raised, one would expect lead to interfere with the internal metabolism of the red cell by an effect on the sulphhydryl (SH-) group enzymes in the EmbdenMeyerhof pathway of glucose metabolism. This may explain why some workers (Griggs and Harris, 1958; Hutchison and Stark, 1961) have shown a reduction in the life of the red cell in cases of lead poisoning. In support of this we note that Wilkinson (1962) states that lead and other heavy metals probably inhibit certain SH-group enzymes by combining with the essential thiol group present in such enzymes. 
An alternative explanation of the reduced life of the cell is that the defective haemoglobinization produces an anaemia and that this in turn produces the reduction in the life of the red cell.

A fascinating concept is to suggest that the recognized susceptibility some subjects display to the effects of lead is due to an intrinsic enzymic defect, a close analogy of which might be the haemolytic anaemia found in favism and that induced by some anti-malarial drugs (Beutler, 1959) due to a deficiency of the enzyme, glucose-6-phosphate dehydrogenase. It is also interesting to note that it has been shown that glutathione is stable in cases of lead poisoning (McGovern, Isselbacher, Rose, and Grossman, 1958), when incubated with buffered acetyl phenylhydrazine, as opposed to its instability under the same conditions in the other drug-induced haemolytic states.

Although an unstable glutathione is normally associated with a deficiency of glucose-6-phosphate dehydrogenase, this is not invariably so. We have been unable to find references to any work on the levels of the enzymes within the red cell in cases of lead poisoning although the serum enzymes in cases of plumbism have been studied by Casula, Cherchi, Piredda, and Spinazzola (1959), who found no significant abnormalities in the levels of S.G.O.T. and S.G.P.T., aldolase, and malic and lactic dehydrogenases. They found the concentration of certain esterases to be slightly reduced, which they explained by postulating a diminished production of these enzymes by the liver due to the action of lead.

Elevated levels of S.G.O.T. in persons having had exposure to lead have been reported by Waldman and Borman (1959).

Further work in this direction is under way.
Our thanks are due to Professor R. E. Lane for his continued interest in our work and for his valued advice and guidance, to Dr. A. R. Thompson for his encouragement and help, and to the management of Vauxhall Motors for their permission to publish this paper. Our very grateful thanks are also due to Dr. T. Parkinson, consultant physician at the Luton and Dunstable Hospital for arranging for us to have access to his patients.

\section{REFERENCES}

Aub, J. C., Fairhall, L. T., Minot, A. S., and Reznikoff, P. (1926)

Lead Poisoning. Williams \& Wilkins, Baltimore.
Minot, A. S., Fairhall, L. T., and Reznikoff, P. (1924). J. Minot, A. S., Fairhall, L.

Bénard, H., Gajdos, A., and Gajdos-Török, M. (1958). C. R. Soc. Biol.'(Paris), 152, 296.

Beutler, E. (1959). Blood, 14, 103.

Casula, D., Cherchi, P., Piredda, S., and Spinazzola, A. (1959) Rass. med. sarda, $61,847$.

Clarkson, T. W., and Kench, J. E. (1958). Brit. J. industr. Med., 15, 115 .

Dacie, J. V. (1962). Brit. med. J., 2, 429.

de Kretser, A. J., and Waldron, H. A. (1963). Brit. J. industr. Med. 20,35 .

Gajdos-Török, M., Gajdos, A., and Bénard, H. (1958). C. R. Soc. Biol. (Paris), 152, 1689.

Goldberg, A., Ashenbrucker, H., Cartwright, G. E., and Wintrobe, M. M.'(1956). Blood, 11, 821.

Griggs, R. C., and Harris, J. W. (1958). Clin. Res., 6, 188.

Hunter, D. (1962). The Diseases of Occupations, 3rd ed., p. 251. English Universities Press, London.

Hutchison, H. E., and Stark, J. M. (1961). J. clin. Path., 14, 548.

Jandl, J. H., Inman, J. K., Simmons, R. L., and Allen, D. W. (1959). J. clin. Invest., 38, 161 .

McGovern, J. J., Isselbacher, K., Rose, P. J., and Grossman, M. S. (1958). Trans. Soc. pediat. Res. 28th Ann. Meeting, A.M.A. $J$. Dis. Child., 96, 502.

Pearse, H. E. (1926). Arch. int. Med., 37, 715.

Rimington, C. (1938). C.R. Lab. Carlsberg. Ser. Chim., 22, 454. (1951). In Ciba Foundation Conference on Isotopes in Biochemistry. Churchill, London.

Schubothe, H., and Po-Tun Fok, F. (1960). Brit. J. Harmat., 6, 350.

Shen, S. C., Castle, W. B., and Fleming: E. M. (1944). Science, 100, 387.

Vigliani, E. C., and Waldenström, J. (1937). Dtsch. Arch. klin. Med, $180,182$.

Waldman, R. K., and Borman, E. K. (1959). A.M.A. Arch. industr. Hlth, 19, 431 .

Wilkinson, J. H. (1962). An Introduction to Diagnostic Enzymology. Arnold, London.

Young, L. E., Izzo, M. J., and Platzer, R. F. (1951). Blood, 6, 1073. 